\title{
Effective Communication of Product Information: A Copy Writing Methodology
}

\author{
${ }^{1}$ Dandeswar Bisoyi , ${ }^{2}$ Dr Utpal Barua,${ }^{3}$ Esha Guha \\ Dept of Design, Indian Institute of Technology, Guwahati, India \\ Quantum Communications, Delhi ,India
}

\begin{abstract}
Copy writing is a process where advertisers convey the product information to customers. Copy is created to fulfill the needs of its user. In the market, copy should also represent the brand vision that companies want to communicate to their customer. Companies can create strong customer relations and recall by creating memorable messaging. Copywriting is the use of creativity in words or ideas with the focus of selling products through the creation of brands. For copywriting to be effective, one has to be original and interesting in order to influence the buying decisions of millions. In this paper, current theories of copy and models of the copy process, importance of copy in advertisement are discussed.
\end{abstract}

Keywords: Copy writing, Advertisement, Marketing, Branding

\section{Introduction}

The handicap of selling without being in personal contact throws a creative challenge to the copy team. We have to arrest attention and sustain interest by remote control and use copy that has a promise and which people can relate to. It is also the basis on which effective visuals can be created. Mere presentation of information about goods or services gets monotonous and boring; we need to keep our target audience informed as well to keep their interest alive. This is where copywriting "skills" come into play, because the need is to communicate effectively in today's world, one where consumers are bombarded by thousands of messages every day. Copywriting as an integral part of information dissemination in advertising has a vital creative connect.

A simple question with, in most cases, simple answers. IT engineers, IAS officers, journalists and professional skateboarders don't need to give a second thought before answering it. Certain professions are easy to define. Even ambiguous ones like investment banking conjure an image or two. But, ask a copywriter to define what he does and chances are a lot of hums and haws will follow. Why? Because copywriting just isn't a simple profession to explain.

Copywriting is the only function in advertising that requires no academic qualifications. Anyone from a mechanic to a Harvard graduate can become a copywriter. For the most part, they are a motley crew of people who stumble into the profession. The only constant truth is that no one grows up dreaming about becoming a copywriter. So here are the basic questions. Is copywriting an integral part of advertising? Yes. Does it require a certain amount of word craft? Yes. Is that all it is? No. Below is an exploration into this most confusing of job definitions.

\section{What Is Copywriting?}

Copywriting is unique as a creative profession. Firstly because unlike other creative professions, it starts by carefully considering the end consumer and understanding that consumer's reality and that consideration informs and guides the entire copywriting process. Secondly because it aims at the broadest possible denominator and works to create communication that is mostly inclusive. And finally because copywriting is not just the art of saying something well, but more importantly it's the art of saying it simply and effectively. In fact, it would be safe to say that it's not just the art of writing. It's the business of writing.

\section{The Art Of Copywriting}

Someone once said that give typewriters to a room full of monkeys, and eventually you'll get Shakespeare. While that may or may not be true, copywriting takes a little more than opposable thumbs. In a world where the average consumer is inundated with a plethora of messages from thousands of brands every week, and where the unique selling proposition is a dream of the distant past, creativity is one of the few weapons left in a copywriter's arsenal.

In almost every creative field, parameters rarely enter the picture and the individual works for the sake of creativity itself. The art of copywriting lies not just in putting some words together and making them sound nice. It lies in the fact that advertising is a business, and therefore has a bottom line. This is turn creates parameters which must be adhered to. Copywriting is in fact, the art of writing the right line, at the right time for 
the right results. It means creating ideas that can be understood by a large base of people and then enjoyed by them. And it does mean playing with words and creating communication that doesn't make the consumer want to reach for a dictionary. The art of copy writing, in short, is thinking of the best idea in a set of business parameters, and finding the best possible way of articulating that idea to achieve the bottom line.

\section{The Methodology Of Copywriting}

Copywriting isn't nuclear physics. It doesn't have a series of set rules that have to be followed, and methods are as subjective as the work they produce. With this as a given, there are a set of broad steps that copy writers follow to get to the final advertisement. While approaches might vary, there is a broad process which is listed below:

1. Understanding the Brief: The brief is the copywriter's only real guide to the client's requirements. It creates a story for the writer to work with. It sets the context for the communication and defines the parameters of the job.

2. Deconstructing the Brief: Once briefed, most writers study each individual part of the brief in itself. Who are they talking to? Why is there a need to talk? What is the desired result? Just a few of the questions a copywriter must find satisfactory answers to.

3. Absorbing the Proposition: While there are innumerable definitions for the creative proposition, the simplest is this: A creative proposition is a one line brief on what must be said by the client to the brand's audience in order to achieve the desired result. Or put more simply, what are we saying?

4. The Creative Leap: This is where the creative process for the copywriter truly begins. Once the basics are known and the proposition decoded, the copywriter along with his art partner must create a campaign from the proposition. This entails a process of finding the most interesting, inventive and memorable way of communicating with the given audience.

5. The Communication Idea: The idea comes from the leap. The communication idea has only one raison d' etre. To create a disruption in the mind of the consumer, making the communication memorable and interesting.

6. The Communication: Once the idea has been decided upon, the copywriter will then create the communication with his art partner providing all copy elements for the communication in its various forms. This includes everything from TV scripts to brochure copy.

Good copy is an expression of the brand qualities, it is their standard bearer. The goal of the copywriter is to get the consumer's attention, generate interest in the brand and then build reliability for the brand's claims. The following elements should be present in every ad:

- Attention

- Interest

- Credibility

- Desire

- Action

1.1 Attention: Copy grabs the attention of the targeted consumer with appropriate messaging.

1.2 Interest: The communication then generates interest vis-à-vis the brand by using the best possible psychological, physical or need-based hook.

1.3 Credibility: The third stage requires that the consumer buy in to the brand claim with the help of facts that act as credible substantiation.

1.4 Desire: After having grabbed attention, generated interest and substantiated the brand, good communication now creates a desire to own the brand.

1.5 Action: In the final stage, desire to own the brand instigates the consumer to physically interact with it. Note: Communication does NOT instigate the consumer into purchase. Good communication can lead the consumer to a brand's doorstep, but the brand experience delivers the rest.

\section{Role Of Different Elements In Copy}

Copy writing includes Headlines, Sub headlines, Tag lines, Jingles, TV commercial scripts, Body copy, Slogans, Direct mailers etc. We understand the object of good copy. Let's examine the basic copy elements.

1.1 Headlines: The headline is considered to be the most important element in an ad .The objective of headlines is to create attention and attractiveness amongst customers. Headlines announce the promise of the brand to the consumer. 
1.2 Sub headline: Sub headlines carry facts that can be substantiation for the claims of the headline. They can also be used to highlight a specific feature which deserves special attention. In short, sub headlines are used to complete the main messaging of the ad.

1.3 Slogans: Slogans are short and pointedly focused. They reduce an ad advertising message strategy to a brief, repeatable and memorable positioning statement.

○ The slogan is simple and straight-forward

- It emphasizes the communication idea

- It conveys more in a compact form

○ Good slogans finish in 7-8 words

1.4 Body copy: The advertiser tells the complete communication story in the body copy or text. The body copy covers the features, benefits and utility of the product or service. In the body copy the writer must speak to the readers self interest, explaining how the product or service satisfies the customers need. The text may concentrate on one or several benefits.

1.5 Tag line: The tag line is a variant of a slogan typically used in marketing materials and advertising. The idea behind the tag line is to create a memorable phrase that will sum up the tone and premise of a brand or a product or to reinforce the audience's memory of a product. A tag line is also known as a base line, catch line or a punch line.

1.6 Jingles: These are catchy little tunes which we pick up and hum quite unconsciously most of the times like a refrain registered in our brain which refuses to go away. Jingles make possible the association of memorable phrases with the product or with the company

1.7 Direct mail: Direct mail is medium to contact a prospect directly and elicit a response without the intervention of a retailer or sales person. Direct mail is a valuable way to tell your customer who you are and what your business offers.

\section{Conclusion}

In the incredibly crowded reality that we call today's market, every brand is at constant war for a portion of the consumer's all important consideration set. With homogeneity in production setting in for almost all brands across every category, the unique selling proposition is an antiquated concept. Therefore, the only true differentiation for most brands is in their communication. Not only is perception the king of the marketing game, but good communication can make it reality. And it is in this scenario, that the art and business of copywriting has truly come of age. Changing times and increasing competition because of which everyone's running sort of time and also because of modern approach of creativity in which visual are more dominating today's ads but still copy is very vital as it completes the ad gives life to it and influence the decision of millions.

\section{Books:}

\section{References}

[1] S.A.Chunawalla \& K.C.Sethia Foundations of advertising theory and practice (Himalaya Publishing House,Mumbi,2005)

[2] William wells, john Burnett \& Sandra moriarty Advertising Principles and Practice (NJ: Prentice-Hall,Inc,2000).

\section{Chapters in Books:}

[3] Advertising copy for Print media in S.A.Chunawalla \& K.C.Sethia (Ed.) Foundations of advertising theory and practice (Himalaya Publishing House, Mumbi, 2005)

[4] Copy writing for TV, radio and outdoor media in S.A.Chunawalla \& K.C.Sethia (Ed.) Foundations of advertising theory and practice (Himalaya Publishing House, Mumbi, 2005)

[5] Creating print advertising, in William wells, john Burnett \& Sandra moriarty (Ed.) Advertising Principles \& Practice.5 (Nj:Prentice-Hall, 2000)323-326 